\title{
СУЧАСНА ПАРАДИГМА СИСТЕМИ ЗАПОБІГАННЯ ЗЛОЧИННОСТІ НЕПОВНОЛІТНІХ
}

\author{
БУНДЗ Ростислав Олегович - кандидат юридичних наук, асистент кафедри \\ кримінального права і процесу Інституту права, психології та інноваційної освіти \\ Національного університету «Львівська політехніка» \\ ORCID ID: https://orcid.org/ 0000-0002-3651-4068 \\ КАНЦІР Володимир Степанович - доктор юридичних наук, професор, \\ професор кафедри кримінального права і процесу Навчально-наукового інститут \\ права, психології та інноваційної освіти Національного університету «Львівська \\ політехніка" \\ ORCID ID: https://orcid.org/ 0000-0002-3689-4697 \\ DOI 10.32782/LAW.UA.2021.3.16
}

У статті на основі аналізу спеціальної наукової літератури та чинного законодавства окреслено шляхи запобігання злочинності неповнолітніх, проведено моніторинг доцільності диберенціаціӥ вікових груп неповнолітніх, встановлено причинно-наслідкові кореляиійні зв'язки між зазначеним видом злочинності та факторами впливу.

Небезпека зростання рівня злочинності неповнолітніх полягає в тому, що особи, які почали вчиняти злочини у ранньому віці, у подальшому значно важче піддаються виправленню $i$, зрештою, становлять основний «резерв» для повнолітнъої й рецидивної злочинності, а також організованої злочинності. Відтак раннє виявлення та своєчасне вжиття профілактичних заходів до неповнолітніх правопорушників зазвичай створюють передумови недопущення формування у изи осіб стійкої спрямованості на вчинення у подальшому будь-яких злочинів.

Констатовано, що формування антисочіальної поведінки у неповнолітніх - цее процес накопичення особистісних дебормачій у сберах потреб, інтересів, изннісних орієнтаиій.

Визначено, що в умовах съогодення відсутні уніббіковані підходи щодо значення $і$ впливу особистісних особливостей неповнолітніх на їхню злочинну поведінку, адже такий тип злочинності є надзвичайно латентним й схильним до рециидиву.

Рекомендовано на макрорівні імплементувати загальносоиіальне попередження зло- чинів, які вчиняються неповнолітніми, як діяльність державних органів, громадських організачій, суспільства та окремих громадян, що має довготривалий характер, $i$ враховує специбіку об'єкта попередження, спрямовану на усунення, ослаблення, нейтралізацію негативного комплексу впливу на злочинність, a також виникнення антикриміногенних чинників, сигналом для яких має бути антигромадсъкий вчинок людини, їі протиправна поведінка, яка може перетворитися на установку на вчинення злочину з особливою жорстокістю.

До заходів попередження злочинів, що вчиняються неповнолітніми, доцільно віднести: культурно-виховну роботу у всіх сберах діяльності; апроксимачію культури сімейного виховання; бормування сочіально орієнтованої особистості з певними суспільно визнаними морально-етичними иінностями; боротьбу 3 рецидивною злочинністю; зниження пропаганди насильства у ЗМI; імплементацію механізму міжвідомчої взаємодї з проббілактики злочинності неповнолітніх; бормування безпекового середовища та ін.

Ключові слова: насильство, злочини, правопорушення, неповнолітні, профілактика правопорушень серед неповнолітніх, соціалізаиія.

\section{Постановка проблеми}

В умовах сьогодення у нашій державі спостерігається динамічне зростання рівня 
злочинності неповнолітніх, зокрема, надвисокою є і латентна злочинність цього виду. Спостерігається зміна характеру злочинності неповнолітніх, зокрема, простежується перманентність рецидиву кримінальних правопорушень, вчинених неповнолітніми з особливою жорстокістю та досить високим рівнем «професіоналізму». Пересторогою для суспільства слугує те, що на загал така злочинність дедалі більше набуває групового характеру, що вимагає нагальної імплементації системи превентивних заходів запобігання злочинності неповнолітніх у всі сфери життедіяльності. Небезпека зростання рівня злочинності неповнолітніх полягає у тому, що особи, які почали вчиняти кримінальні правопорушення у ранньому віці, у подальшому значно важче піддаються виправленню i, зрештою, становлять основний «резерв» для повнолітньої й рецидивної злочинності, а також організованої злочинності. Відтак раннє виявлення та своєчасне вжиття профілактичних заходів до неповнолітніх правопорушників зазвичай створюють передумови недопущення формування у цих осіб стійкої спрямованості на вчинення у подальшому будь-яких кримінальних правопорушень.

\section{Мета статті}

Комплексний аналіз злочинності неповнолітніх, моніторинг загальносоціальних заходів запобігання кримінальним правопорушеннями, що вчиняються неповнолітніми. Формування сучасної платформи превентивних заходів попередження кримінальних правопорушень, що вчиняються неповнолітніми, 3 акцентом на оцінку ризиків, на соціалізацію, інформаційну та психологічну підтримку, формування цільових програм.

\section{Ступінь дослідженості теми}

Дослідженню різних аспектів злочинності неповнолітніх присвячено низку наукових досліджень, зокрема проблематика злочинності неповнолітніх та формування системи запобігання зазначеному виду кримінальних правопорушень, аналізується у працях Ю. А. Амбросімової, Д. А. Виговського, В. Г. Дідківської, А. П. Гусака,
В. А. Мозгової, Н. Д. Туза, Н. С. Юзікової та інших учених та фахівців. Проте, питання запобігання злочинності неповнолітніх, вимагає постійного моніторингу та корегування відповідно до норм чинного законодавства та вимог часу.

\section{Виклад основного матеріалу}

У кримінології злочинність неповнолітніх виокремлюється у самостійний вид злочинності, який перебуває у центрі уваги вчених та практиків. Це обумовлюється тим, що неповнолітні особи виступають «заручники» вимог часу; правил поведінки, що часто штучно нав'язані певним соціумом; браком культури та виховання.

Соціально-економічна криза в Україні, безробіття, невирішені завдання культурно-виховного характеру інтенсивно впливають на формування молодого покоління. В окремих випадках ці явища зумовлюють відчуження неповнолітніх від офіційних інститутів соціалізації, таких як сім'я, школа тощо [1, с. 263].

Необхідність виокремлення злочинності неповнолітніх у самостійне кримінологічне дослідження обгрунтовується низкою фабул, зокрема:

- генеза та мотивація злочинності неповнолітніх безпосередньо обумовлена специфікою виховання, особистісного та психологічного розвитку, рівнем соціалізації;

- формування системи заходів запобігання поширенню рівня злочинності неповнолітніх як однієї із найменш захищених соціальних груп - одне 3 найважливіших завдань як органів державної влади, так і суспільства загалом, адже від ії ефективності багато в чому залежить стан й тенденції злочинності у майбутньому і навіть, що не менш важливо, - моральний клімат у суспільстві;

- доцільність формування у Кримінальному кодексі України окремого розділу, у якому закріплено особливості кримінальної відповідальності і покарання неповнолітніх, адже Кримінальним кодексом України встановлено вікові критерії для виділення неповнолітніх в окрему демографічну групу злочинців (нижня межа - 14 років, верхня - 16 років), що має досить умовний 


\section{Кримінальне право, кримінальний процес та криміналістика}

характер, хоча й обумовлені вимогами вікової психології і кримінальної політики.

Очевидно, що злочинність неповнолітніх та злочинність молоді мають чимало спільних ознак, проте, за висновками вікової психології, самостійні судження про навколишне оточення з'являються у підлітка десь близько 11-12 років за принципом «що є добре і що погано». Приблизно у 14-16 років на грунті цих суджень формуються переконання, які утверджуються у суперечках i дискусіях як власні погляди, і вже до 18, а то й 20 років на підставі відфільтрованих, сформованих суджень активно формується світогляд - як стійкій психологічний, ментальний феномен, який, головно, і визначає майбутнє підлітка [2, с.242-243].

Подібної позиції дотримується вітчизняна учена В. А. Мозгова, яка розглядає злочинність неповнолітніх як відносно масовий соціальний феномен, що виражається у статистичній сукупності фактів протиправної (кримінально забороненої) поведінки суб'єктів злочину віком від 14 до 18 років на певній території за відповідний період часу [3, с. 143].

Злочинність неповнолітніх - це негативне соціальне явище, що має саморегулюю- чу сукупність взаємопов'язаних елементів, швидко реагує на зміни в суспільстві як вид злочинності, специфіка якої зумовлена ймовірнісними величинами, що отримуються внаслідок вивчення злочинів і осіб, що їх вчиняють у віці 14-17 років [4, с. 24]. Відтак можна стверджувати, що неповнолітні віком до 18 років набувають, крім соціальних, ще й психологічних і психофізіологічних особливостей, які безпосередньо впливають на їхню поведінку. Це ще не означає, що дослідження злочинності неповнолітніх і формування заходів щодо запобігання їй не мають грунтуватися на загальних положеннях наук кримінології і кримінального права, на загальній концепції політики боротьби зі злочинністю.

Зазначені вище позиції вчених щодо вікової диференціації злочинності неповнолітніх є слушними, про що свідчить статистика офісу Генерального прокурора, щодо рівня злочинності серед вікових груп (рис. 1).

Причиною підліткової злочинності найчастіше $\epsilon$ неналежний догляд за дітьми батьків або їхня відсутність. Загальне зниження рівня життя, неблагополуччя сімей, які з втратою прибутку втрачають і мораль-

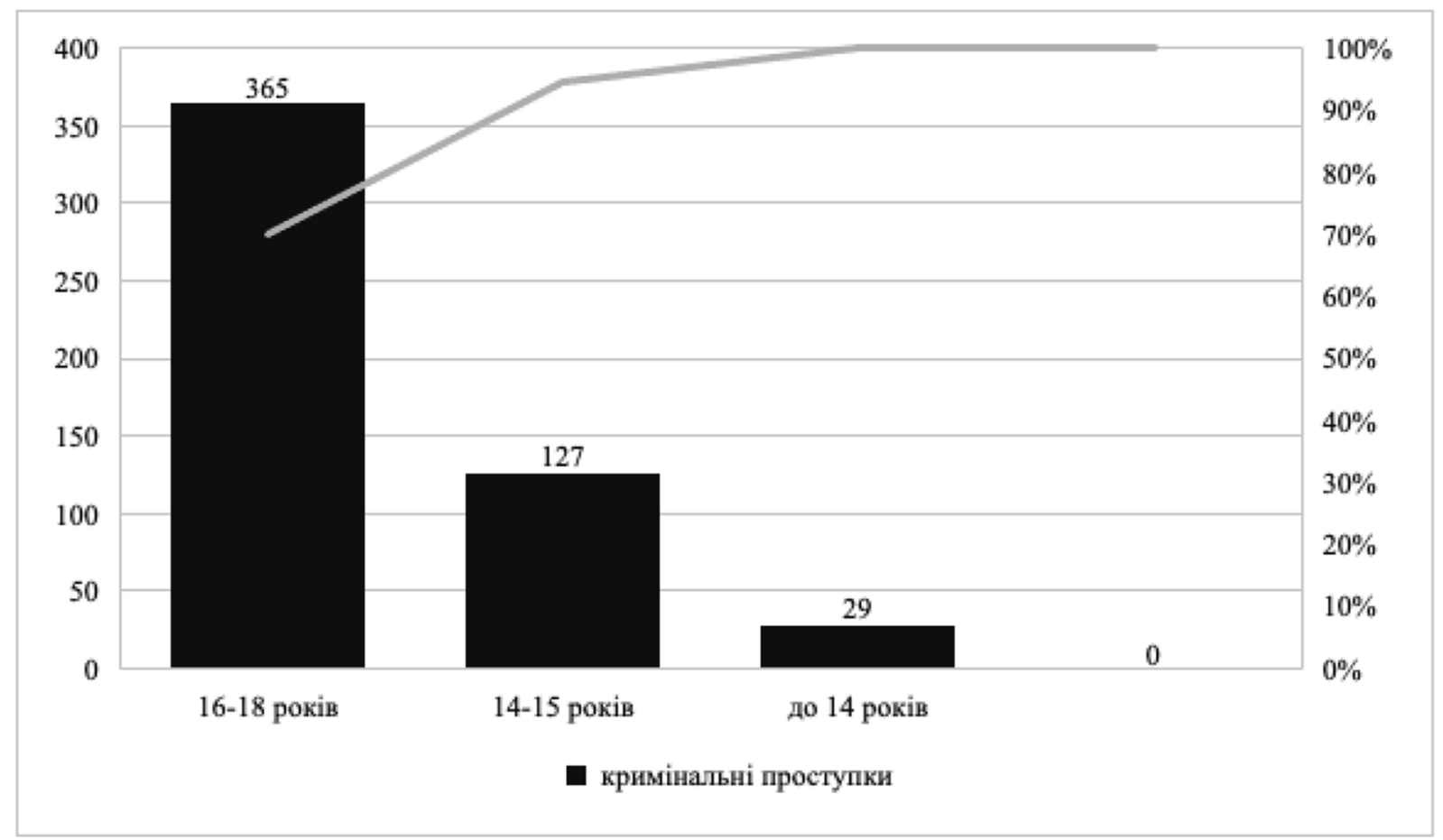

Рис. 1. Диференціація кримінальних правопорушень у розрізі вікових груп неповнолітніx [5]. 
Бундз Р.О., Канцір В.С. - Сучасна парадигма системи запобігання злочинності...

ні цінності, відсутність нормальних побутових умов - усе це призводить до того, що діти, прагнучи жити так, як усі, намагаються досягти цього шляхом крадіжок та інших кримінальних правопорушень. Окрім того, згубний вплив на неповнолітніх справляє телебачення, що пропагує насильство і життя заради власного задоволення.

Контент-аналіз джерел отримання кримінально-правових знань та інформації показав: провідну роль у наданні правової інформації батьками, превалювання у правовому вихованні неповнолітніх неофіційних джерел правової інформації; суттєву різницю в оцінці своєї правової роботи серед неповнолітніх учителями й неповнолітніми. у межах формування правосвідомості неповнолітніх у цілому та кримінально-правової сфери зокрема, на нашу думку, доцільно зосередити увагу на: пропаганді законослухняної поведінки та ії̈ переваг у процесі формування особистості неповнолітнього і домінування правомірної мотивації у вирішенні конфліктних ситуацій; інформуванні 3 питань кримінальної відповідальності та заходів кримінально-правового і примусового виховного характеру; набутті життєво важливих навичок, навчанні задоволення потреб та інтересів і вирішення конфліктів правомірним шляхом [6].

Проте, нині відсутні єдині підходи щодо значення і впливу особистісних особливостей неповнолітніх на їхню злочинну поведінку. Відтак, для вироблення наукових підходів до дослідження злочинності неповнолітніх необхідною і важливою умовою $\varepsilon$ встановлення природи цих особливостей (соціальні чи генетичні або ж співвідношення у їх поєднанні) та правильне трактування їх значення у структурі чинників, що зумовлюють злочинність неповнолітніх.

Формування антисоціальної поведінки у неповнолітніх - це процес накопичення особистісних деформацій у сферах потреб, інтересів, ціннісних орієнтацій. В умовах несприятливого формування особи виникає невідповідність між ії рисами й якостями і вимогами навколишньої дійсності. Особа виявляється не адаптованою до навколишнього соціального середовища, у якому повинна жити, навчатись, працювати.
За кримінологічними показниками, злочинність серед неповнолітніх у структурі злочинності загалом по Україні протягом найближчих років має поступово зменшуватися або зберігатиметься на тому ж рівні. Усе залежатиме від суттєвих демографічних змін, покращення стану в економічній та сімейно-побутовій сферах, розвитку правової демократичної держави, у законотворчій та правозастосовній діяльності щодо запобігання злочинності серед неповнолітніх. При цьому серед областей України вітчизняні кримінологи О.М. Аитвак іI.В. Однолько виділяють найбільшу кількість вчинення неповнолітніми наркозлочинів у Дніпропетровській, Ауганській, Донецькій, Харківській і Київській областях [7, с. 123].

Порівнюючи злочинність неповнолітніх у різних регіонах, дослідники виявили таку закономірність: відносно стійка залежність між рівнем злочинності неповнолітніх у такому регіоні і такими показниками, як частина неповнолітніх, які не працюють і не навчаються; концентрація осіб, які були засуджені, побутових правопорушників, осіб, які перебувають на різних обліках (алкоголіки, наркомани, психічно хворі); кількість сімей, що розпалися, у яких були діти; кількість сімей, у яких один із батьків або ж обоє тривалий час працюють за кордоном; рівень безробіття в регіоні.

Саме у регіонах зі складною соціальною ситуацією простежується вищий рівень злочинності неповнолітніх. Тож сімейне неблагополуччя в найширшому соціальному розумінні $є$ чи не найважливішим показником, що впливає на стан і подальші тенденції у злочинності неповнолітніх. Сімейна стабільність акумулює різноманітні негативні процеси і явища економічного, політичного, етико-виховного, демографічного, соціально-психологічного характеру, що відбуваються у суспільстві і детермінують поведінку неповнолітнього та визначають iï характер. Ці процеси загалом визначають умови життя у суспільстві і, відповідно, коригують навчальний та виховний процеси, формування особистості неповнолітніх. Зокрема, до процесів, що створюють негативні умови для життя і виховання неповнолітніх, останніми роками в Україні належать: 


\section{Кримінальне право, кримінальний процес та криміналістика}

- значна соціальна диференціація населення;

- порушення принципу розподілу i перерозподілу матеріальних благ і їх споживання залежно від інтенсивності та соціальної значущості власної праці;

різниця у характері і змісті навчання залежно від матеріального становища; високий рівень розлучень та розпаду сімей, що супроводжується суттєвими змінами у вихованні неповнолітніх;

- поширення пияцтва та алкоголізму, нервово-психічних розладів, хронічних захворювань окремих груп населення;

- духовна розбещеність;

- низький рівень правової культури у суспільстві і значна деформація моральної та правової свідомості окремих верств населення; вимушена необхідність батьків працювати за кордоном окремо від сім ї; недостатнє ресурсне і кадрове забезпечення суб'єктів, які займаються вихованням неповнолітніх.

Специфіка впливу перелічених і інших соціальних процесів та явищ на поведінку неповнолітніх, на відміну від повнолітніх, полягає у більш опосередкованому впливі на них (і позитивному, і негативному) через навколишнє середовище.

Порівнюючи кількісні показники злочинності неповнолітніх із дорослою, слід зважати на те, що перша охоплює всього чотирирічний період людського життя, а друга - десятиліття, починаючи від 18 років. Відрізняються вони й якісно. Скажімо, неповнолітні не вчиняють посадові злочини у сфері економіки тощо. Для злочинності неповнолітніх властива підвищена латентність, оскільки багато їх діянь сприймаються як пустощі, викликані недостатньою соціальною зрілістю (крадіжки у сім'ї, сусідів чи навчальному закладі; хуліганські бійки, відбирання грошей та речей у молодших тощо). Про такі вчинки, за прави^о, не повідомляють до правоохоронних органів. Тому реальнішим є облік тяжких насильницьких і насильницько-корисливих злочинів, які скоюють неповнолітні, убивства, тяжкі тілесні ушкодження, згвалтування, злісне хуліганство, грабежі та розбійні напади.
Особи, які вчиняють протиправні дії у ранньому віці, згодом важче піддаються виправленню і в результаті утворюють основний «резерв» для рецидивної злочинності. I навпаки, щонайраніше вжиття профілактичних заходів до підлітків, які вчиняють дрібні правопорушення, значно сприятиме недопущенню формування у них кримінальної спрямованості.

Відтак сучасне суспільство має гостру потребу в надійному гарантуванні безпеки громадян. Зокрема, особлива увага населення і правоохоронних органів прикута до злочинів, що посягають на життя, здоров'я, честь, гідність людини, що вчиняються особами, які не досягли повнолітнього віку. Такі злочини є найбільш небезпечними видами кримінальних посягань на основну цінність суспільства - людину і заподіюють величезний за масштабами і непоправну за характером наслідків шкоду потерпілому i суспільству загалом.

Загалом специфіка тяжкої насильницької злочинності неповнолітніх може бути розглянута як обумовлена комплексом взаємопов'язаних чинників, що належать до вікових, соціальних, психологічних особливостей неповнолітніх, специфіка їх соціального статусу. Встановлення специфічних рис, які обумовлюють поведінку неповнолітніх, що порушує права, особливості його якісних і кількісних параметрів, їх аналіз 6 основою для розроблення заходів запобігання, орієнтованих на застосування щодо цієї вікової групи.

Профілактика правопорушень серед неповнолітніх залишається єдиним робочим механізмом зміни ситуації, але тільки в межах міжвідомчої взаємодії всіх суб'єктів. Адже на ці виклики може відповісти тільки консолідоване професійне співтовариство, що поділяє і приймає нові форми роботи [с. 8]:

- рання психолого-педагогічна корекція агресивної поведінки дітей при взаємодії батьків і школи;

- індивідуальна робота 3 проблемними сім'ями із залученням широкої громадськості;

- збільшення кількості та підвищення якості послуг позашкільної освіти та дозвілᄉя; 
- психологізація та педагогізація спеціальних засобів профілактики злочинності неповнолітніх;

- координація заходів та взаємодія підрозділів ювенальної превенції, освітніх закладів та спеціальних установ.

В Україні сформовано та поетапно проводиться реалізація Національної стратегії реформування системи юстиції щодо дітей на період до 2023 року [9], яка регламентує механізм забезпечення системного підходу до профілактики злочинності серед дітей, шляхом реалізації відповідних завдань:

- запровадження механізму міжвідомчої координації дій з метою профілактики правопорушень серед дітей;

- удосконалення діяльності органів виконавчої влади та органів місцевого самоврядування, спрямованої на проведення оцінки потреб населення у соціальних послугах, зокрема у соціальній профілактиці, 3 метою запобігання правопорушень серед дітей;

- забезпечення створення безпечного середовища та зниження рівня злочинності;

- збільшення кількості заходів 3 профілактики правопорушень під час розроблення програм соціально-економічного розвитку, спрямованих на забезпечення працевлаштування, розвитку освіти, охорони здоров'я, надання соціальних послуг, благоустрою, подолання бідності;

- розроблення і виконання різних за видами, змістом, особливостями цільових груп програм профілактики правопорушень серед дітей для застосування органами, установами та закладами з урахуванням положень про їх діяльність, зокрема закладами догляду та виховання дітей;

запровадження проведення оцінки ризиків вчинення правопорушень дітьми та виконання програм, орієнтованих на усунення факторів, що сприяють вчиненню правопорушень дітьми, які схильні до протиправної поведінки;

- запровадження системи моніторингу ефективності програм профілактики правопорушень серед дітей із залученням до його проведення громадських об'єднань;

- вжиття заходів для забезпечення діяльності фахівців із соціальної роботи у те- риторіальних громадах як координаторів організації роботи 3 виявлення осіб/сімей, які перебувають у складних життєвих обставинах, для своєчасного реагування на ризики вчинення правопорушень дітьми, які проживають у таких сім'ях;

- удосконалення системи підготовки, підвищення кваліфікації фахівців, залучених до виконання профілактичних та корекційних програм, проведення моніторингу їх ефективності, оцінки ризиків вчинення правопорушень дітьми;

- проведення систематичної інформаційної роботи із запобігання злочинності серед дітей з урахуванням регіональних, гендерних чи інших особливостей.

\section{Висновки}

Загальносоціальне попередження злочинів, які вчиняються неповнолітніми, - це діяльність державних органів, громадських організацій, суспільства та окремих громадян, що має довготривалий характер i враховує специфіку об'єкта попередження, спрямовану на усунення, ослаблення, нейтралізацію негативного комплексу впливу на злочинність, а також виникнення антикриміногенних чинників, сигналом для якої має бути антигромадський вчинок людини, iї протиправна поведінка, яка може перетворитися на «установку» на вчинення злочину з особливою жорстокістю.

До заходів попередження злочинів, що вчиняються неповнолітніми, доцільно віднести: культурно-виховну роботу у всіх сферах діяльності; апроксимацію культури сімейного виховання; формування соціально орієнтованої особистості з певними суспільно визнаними морально-етичними цінностями; боротьбу з рецидивною злочинністю; зниження пропаганди насильства у ЗМІ; імплементацію механізму міжвідомчої взаємодії з профілактики злочинності неповнолітніх; формування безпекового середовища та ін.

\section{Мiтература}

1. Головійчук $\lambda$. Особливості кримінальної відповідальності неповнолітніх. Підприємництво, господарство і право. 2019. № 3. C. 263-267. 


\section{Кримінальне право, кримінальний процес та криміналістика}

2. Ишаков С. М. Криминология : учебник. М.: Юриспруденция, 2000.

3. Мозгова В. А. Поняття та особливості злочинності неповнолітніх. Юридичний вісник. 2014. № 2 (31). С. 142-147.

4. Дідківська Г.В. Сімейне неблагополуччя в системі детермінантів злочинності неповнолітніх в Україні : монографія. Вінниця : Нілан ЛТД, 2017. 220 с.

5. Сдиний звітпро осіб, які вчинили кримінальні правопорушення за січень-грудень 2020 року: затверджено Наказом Генерального прокурора № 299 від 30.06.2020 р. URL : https://old.gp.gov.ua/ua/stst2011.html?dir $\mathrm{id}=114141 \&$ libid $=100820 \& \mathrm{c}=$ edit\&_c $=\overline{\mathrm{fo}}$ (дата звернення: 27.09.2021).

6. Юзікова Н. С. Злочинність неповнолітніх: закономірності розвитку, теорія та практика запобігання і протидії їй в Україні : автореф. дис. ... д-ра юрид. наук : 12.00.08; МВС України, Харк. нац. ун-т внутр. справ. Харків, 2017. 38 с.

7. ЛитвакО.М.ОднолькоІ.В.Запобігання наркозлочинності неповнолітніх в Україні кримінально-правовими засобами : монографія. Дніпропетровськ : ДДУВС, 2012. 268 с.

8. Гачак-Величко А.А.Адміністративноправове регулювання профілактики правопорушень серед неповнолітніх : : автореф. дис. ... к. юрид. наук : 12.00.07: Національний університет «Львівська політехніка». Львів 2021. 22 c.

9. Національна стратегія реформування системи юстиції щодо дітей на період до 2023 року : Розпорядження Кабінету міністрів України № 1335-р від 27.11. 2019. URL : https:/zakon.rada.gov.ua/laws/ show/1335-2019-\%D1\%80\#Text (дата звернення: 27.09.2021).

\section{SUMMARY}

Based on the analysis of special scientific literature and current legislation, the article outlines ways to prevent juvenile delinquency, monitors the feasibility of differentiating age groups of juveniles, and establishes causal correlations between this type of crime and influencing factors.

The danger of an increase in juvenile delinquency is that those who start committing crimes at an early age are much more difficult to correct and, ultimately, constitute the main "reserve" for adult and recidivism, as well as organized crime. Therefore, early detection and timely take of preventive measures against juvenile offenders usually create the preconditions for preventing the formation of a stable orientation in these persons to commit any further crimes.

It was stated that the formation of antisocial behavior in minors is a process of accumulation of personal deformations in the spheres of needs, interests, value orientations.

It was determined that there are no unified approaches to the importance and influence of personal characteristics of minors on their criminal behavior in today's conditions because this type of crime is extremely latent and prone to recurrence.

It was is recommended to implement general social prevention of juvenile delinquency at the macro level, as a long-term activity of state bodies, public organizations, society, and individuals, and takes into account the specifics of the object of prevention, aimed at eliminating, mitigating, neutralizing the negative impact of crime, as well as the emergence of anti-criminogenic factors, the signal for which should be an antisocial act of a person, his illegal behavior, which may develop and turn into an attitude to commit a crime with extreme cruelty.

Measures to prevent crimes committed by minors should include cultural and educational work in all spheres of activity; approximation of the culture of family upbringing; formation of a socially-oriented personality with certain socially recognized moral and ethical values; fight against recidivism; reduction of propaganda of violence in the media; implementation of the mechanism of interdepartmental cooperation on prevention of juvenile delinquency; formation of a safe environment, etc.

Keywords: violence, crimes, offenses, minors, prevention of offenses among minors, socialization. 